\title{
Gonadal Teratoma
}

National Cancer Institute

\section{Source}

National Cancer Institute. Gonadal Teratoma. NCI Thesaurus. Code C98291.

A teratoma that arises from the testis or ovary. 